
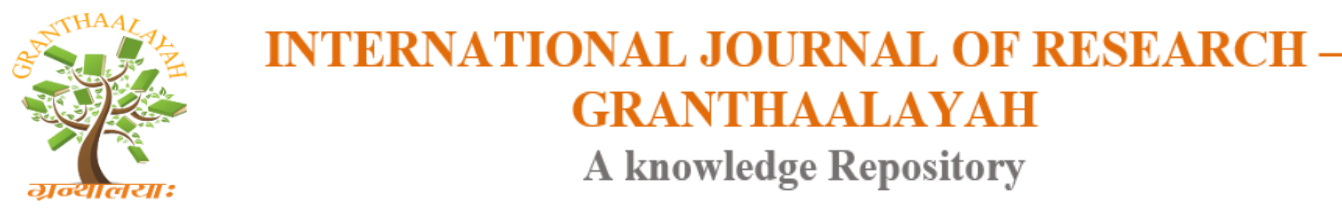

Management

\title{
THE ROLE OF FINANCIAL DEVELOPMENT AND INSTITUTIONAL QUALITY ON ENVIRONMENTAL SUSTAINABILITY IN SUB-SAHARAN AFRICAN COUNTRIES
}

\author{
Aliyu Alhaji Jibrilla *1 \\ ${ }^{* 1}$ Department of Economics, Faculty of Social and Management Sciences, Adamawa State \\ University, Mubi, Nigeria
}

\begin{abstract}
This study addresses the question of financial development and institutional quality influence on the environmental sustainability of some 13 countries from the sub-Saharan Africa. Relying upon pooled mean group (PMG) for panel data, we provide evidence which suggest that both financial development and institutional quality are statistically significant determinants of per capita carbon dioxide emissions in the region. More specifically, we found that without healthy institutions and sound financial system sub-Saharan African countries might not avoid environmental degradation experienced by advanced nations during their early stage of economic progress. Our results also support the EKC hypothesis in the region. In addition, the paper also shows that more openness to FDI inflows is good for the environment across the SSA. These findings suggest the need for institutional and financial service reform that supports robust environmental conservation.
\end{abstract}

Keywords: Financial Development; Institutional Quality; Sub-Saharan Africa; Environmental Degradation; EKC; PMG.

Cite This Article: Aliyu Alhaji Jibrilla. (2018). “THE ROLE OF FINANCIAL DEVELOPMENT AND INSTITUTIONAL QUALITY ON ENVIRONMENTAL SUSTAINABILITY IN SUBSAHARAN AFRICAN COUNTRIES.” International Journal of Research - Granthaalayah, 6(9), 156-177. https://doi.org/10.5281/zenodo.1436796.

\section{Introduction}

Is it possible for African countries to avoid environmental damage experienced by advanced nations during their early stage of economic growth without altering their development process? Environmental and development literatures have indicated that, although environmental damage is associated with an increase in economic activities and income growth, higher income will ensure better environmental quality (Grossman and Krueger, 1995, Antweiler et al., 2001 among others). Moreover, it is assumed that differences in income among countries determine the degree of environmental stringency, which in turn determines the level of environmental damage (Cagatay and Mihci, 2006; Grossman and Krueger, 1991, Shafik and Bandyopadhya, 1992). Put generally, environmental quality varies directly with country's own income relative to the income of others. 
Raising country's income level has a direct effect on its environmental sustainability, because the negative environmental effect of the increasing scale of economic activities is offset by stringent environmental regulation brought about by higher income.

A number of empirical studies have provided consistent evidence that financial development (FD) improves long-run income growth (Schumpeter, 1934; Goldsmith, 1969; King and Levine, 1993; De Gregorio and Guidotti, 1995; Demetriades and Hussein, 1996; Yang and Yi, 2008 among others). Because of the observed strong connection between environmental quality and income growth, on the one hand, the positive link between financial development and income growth, on the other hand, it would be of great importance to consider the role of financial development in the income-environment nexus. One important reason is that FD or financial intermediation can improve capital efficiency and investment in research and development (R\&D) (see De Gregorio and Guidotti, 1995; Tamazian, Chousa and Vadlamannati, 2009). In turn, this can accelerate advancement in technology and positively affect energy efficiency and hence low pollution emissions (Tamazian and Bhaskara Rao, 2010). But there is believed that FD is quite unimportant in the mitigation of greenhouse gases. Notably, Sadorsky (2010) shows that FD stimulates energy demand, which may increase the carbon intensity in the production activities (Zhang, 2011).

In fact, Zhang (2011) finds that FD harms environmental quality, perhaps through its positive effect on investors and household access to loans/credit, which tend to increase investment in new capital and household consumption of durable commodities such as automobiles, houses and household electric appliances, all of which require more energy use and then more pollution emissions. Since we cannot entirely rule out the possibility that financial development may result in more pollution emissions (Zhang, 2011; Tamazian and Bhaskara Rao, 2010), with better indigenous institutions it can be part of the solution to the environmental problems. Although, there is establish fact that financial development causes economic growth across the sub-Saharan African region (see, for example, Ghirmay, 2004; Wolde-Rufael, 2009), the majority of studies that examine the impact of financial development on the environment are not situated in in the region (except for Shabaz, Tiwari and Nasir, 2013, who investigated the effects of financial development, economic growth, coal consumption and trade openness on carbon dioxide emissions in South Africa) and yet, did not control for the effect of institutional quality.

The relative absence of sub-Saharan African-specific study (in the sample of the available studies), however, makes it difficult to rely on the previous works for comprehensive environmental policy in the region. In addition, although, a number ecological studies in African have claimed to find an inverted-U shaped relationship between per capita income and environmental quality (most recent examples include studies by Shabaz et al., 2013; Osabuohien, Efibi and Gitau, 2014 among others), however, a question arose about the accuracy of these claims. Lind and Mehlum (2010) noted that available literatures on the EKC are practically overwhelmed by uncertainty as they did not appear to be supported by formal test $(\mathrm{s})^{1}$. This development has similarly cast some doubt on the validity of the inverted U-relationship between environmental pollution and per capita income reported in the literature within the context of African countries. Although, Lind and Mehlum (2010) have proposed a technique to test for appropriate inverted U-shaped relationships, including the environmental Kuznets curve, however, best known to us this test has not been specifically applied to sub-Saharan African data.

\footnotetext{
${ }^{1}$ For more theoretical detais, see the original article by Lind and Mehlum (2010)
} 
In an attempt to close these gaps, we empirically investigate the role of financial development and institutional quality as determinants of environmental sustainability in the sub-Saharan African countries. Our objectives also include testing for the presence of an inverted U-shaped in the per capita income-environment nexus across THE Sub-Saharan African (SSA) countries.

The main contributions of this study are twofold. First, evaluating the extent of financial development and institutional influence on the mitigation of pollution emissions strengthens the contributions of this study to environmental sustainability in the region. This is particularly important for policy makers considering that most countries in the region are yet to have a comprehensive environmental policy (see, for example, De Longueville, Hountondji, Henry and Ozer, 2010). Second, this study is among first to use the appropriate test of the U shaped relationship between income and environment, particularly using SSA data. Our believe is that the finding from this study will have significant and valuable implication for policy makers and environmental researchers in the region, particularly from the perspective of environmental policy outlook and future research, respectively.

Using a panel data from 13 sub-Saharan African countries for the period 1984-2013, we establish evidence of a significant link between financial development and environmental quality. Institutional quality is al sofound to be significantly strong and reasonably important in explaining not only the growth effect effect of greenhouse gases across the region.

The remainder of the paper is organized as follows. Section 2 provides a contextual information. Section 3 presents a review of the literature. Section 4 describes the methodology and outlines the models. Section 5 describes the data sources. Section 6 reports the empirical results and, finally, section 7 presents conclusions.

\section{Contextual Information}

Although Africa is often seen as the lowest emitter of carbon dioxide in the world, it remains the region that is more susceptible to environmental hazards because of the increasing poverty rate (Osabuohien $t$ al., 2014). It is estimated that about 60 percent of countries that experienced extreme environmental events are situated in SSA (see Osabuohien, Efibi and Gitau, 2013). Moreover, it has also been observed that between 1984 and 2010, the total $\mathrm{CO}_{2}$ emission from burning FossilFuel has increased by about 53\% in the region (World Bank's WDI, 2013). Environmental degradation can result in a varied range of public health problems including low life expectancy, particularly in the low income countries (Brunekreef, 1997, Chen, Ebenstein, Greenstone and Li, 2013). This in turn can affect human development, especially, children access to education as environmental health consequences such as low life expectancy could lead to a higher dependency ratio and forced child labour. For example, children whose parents died at a young age may be forced to drop out of school and are much more likely of being exploited or of being engaged in child labour.

Although, more economic prosperity or higher income levels can ensure better environmental performance (Grossman and Krueger, 1995), the economic performance of most countries in the sub-Saharan Africa is relatively low and may not be reliable to support a long-lasting environmental protection. Key important factors identified to be responsible for slow economic 
performance in the region include weak institutions which results in development of inappropriate economic policies (see Mabogunje, 1995; Sachs and Warner, 1997). Undoubtedly, significant investments in clean technology and renewable energy are needed to contain environmental challenges that face sub-Saharan African countries. This may, however, require a sound financial system that can ensure a sustainable, long-term financing of a 'green industrial transformation'. For example, well-developed financial services can help stimulate rapid and sustained economic growth that can promote guaranteed access to modern energy services needed to contain the increase of environmental pollution ${ }^{2}$.

Noting that institutions across sub-Saharan African countries are relatively weak, (Sachs and Warner, 1997; Mo Ibrahim, 2014; Uneke, 2010), there may exist a handicap to ensure guaranteed access to modern energy services, especially by the poor and to effective pollution control across the region. Weak institutions, which often lead to economic inefficiencies and lower economic performance (see, for example, Jaimovich and Rud, 2014), may have important implication for dealing with environmental problems.

Whether financial development and institutional quality are in fact important in explaining environmental sustainability in the sub-Saharan African region, at best, remain unresolved issues that warrant further investigation.

\section{Literature Review}

A vast literature empirically examines how per capita income growth affects environmental quality. A typical approach applied in most of these studies is the well-known Environmental Kuznets Curve (EKC), which suggests that beyond certain threshold level of economic progress, environmental problems tend to improve with rising income (Grossman and Krueger, 1991, 1995). Earlier investigators within this context that found evidence of EKC in their studies, although, mostly for local pollutants include Shafik and Bandyopadhya (1992) who reported that with the exception of municipal waste, carbon emissions and dissolved oxygen in rivers, most of the environmental indicators such as access to safe water and urban sanitation as well as deforestation and sulphur oxides improve with rising income. This seems to be consistent with the study by Grossman and Krueger (1995) who find that air and water quality appear to benefit from economic growth once some critical level of income has been reached, thus supporting an inverted- U EKC. The study further argued that EKC inverted U-shaped vary for distinct pollutants and caution its interpretation.

A study by Martínez-Zarzoso and Bengochea-Morancho (2004) incidentally appears to justify conclusions by Shafik and Bandyopadhya (1992) and Grossman and Krueger (1995) that carbon dioxide emission increases monotonically with increasing income. Conversely, a recent study by Hitam and Borhan (2012) found that the initial income -induced carbon dioxide emissions in Malaysia starts improving as income rises, thus supporting inverted EKC. The fact that evidences supporting inverted EKC suggest that more income growth has beneficial effect of reducing pollution emissions, demand for environmental quality improvement hinges on the level of damages made by pollution as a result of economic activities (Verbeke and De Clercq, 2006).

\footnotetext{
${ }^{2}$ Grossman and Krueger (1991) also argues that higher income levels tend to make people demand for better environmental quality, which, in turn, can ultimately lead to development of stringent environmental regulations.
} 
However, if the stringency of environmental policy response depends on the level of economic progress, the very poor countries would likely experience longer periods of worsening environmental conditions with rising GDP (see, Grossman and Krueger, 1995).

It is worth noting that the EKC studies are often estimate reduced-form equation in which environmental quality is largely determined by per capita income (Panayotou, 1997; lieb, 2003; Cole and Neumayer, 2004). This however might not give a full account of why environmental quality would deteriorate with income and improve after certain threshold level of economic progress. A number of environmental analysts that have attempted to provide possible explanation for the inverted U-shape income-environment relationship (Selden and Song, 1994; Grossman and Krueger, 1995; Panayotou, 1997; Antweiler et al., 2001; Cole and Elliott, 2003; Managi et al., 2009) consider decomposing income effects on the environmental quality into scale, composition and technique effects. While the scale effect implies rising pollution with increasing scale of economic activities, change in the composition of production and/or consumption can also alter the pollution level. Over the time, change in technology, especially the one that comes with the cleaner technique of production reduces the level of pollution (Khanna and Plassmann, 2004, Karp, 2011). Some scholars (e.g. Tamazian, Chausa and Vadlamannati, 2009; Tamazian and Bhakara Rao, 2010 among others) have control for financial development in their analyses of how environmental quality can improve with higher income level.

The fundamental idea reminds us that at a higher income level there is tendency for citizens to mount pressure on the government to control pollution level by means of stringent environmental policies. Tamazian et al. (2009) argued that since economic progress reflects changes in the structure of national production, including growth in the financial sector, then it suggests that if the environmental performance changes with the income level, financial development affect pollution indirectly through income.

There is an emergent body of researchers seeking to establish whether financial development is good or bad for the environment. Many contributors to the ongoing debate, argue that more financial development would lead to a better performance of environmental quality (see, for example, Tamazian, Chausa and Vadlamannati, 2009; Tamazian and Bhakara Rao, 2010; Jalil and Feridun, 2011; Shabaz, Hye, Tiwari and Leitao, 2013; Shabaz, Tiwari and Nasir, 2013 among others). On the contrary, while Ozturk and Acaravci (2013) reported that FD has no significant effect on per capita $\mathrm{CO}_{2}$ emissions in Turkey, Zhang (2011) finds that Chinese financial development significantly increases carbon emissions ${ }^{3}$. The general idea from the previous literature which indicates non-conclusive argument relating to financial development and environmental performance suggests some advantage of more empirical investigation.

In light of these conflicting findings, scholars reflected the possibility that the effect of FD on the environmental quality is conditional on the presence or absence of other explanatory variables. Tamazian and Bhaskara Rao (2010) among others proposed that besides financial development, healthier institution is one possible key factor that might better explain environmental sustainability. For example, strong institutions that allow access to credit of domestic firms may

\footnotetext{
${ }^{3}$ Ziaei (2015) has summarized studies that controlled for financial development in the environment-income growth nexus, but with the exception of institutional quality, there is very limited works exploring the effects of institutions on environmental performance.
} 
have positive link with greater capital efficiency and new investment in RandD that can facilitate the provision of environmental facilities (Tamazian and Bhaskara Rao, 2010). Moreover, there is agreement that collective control of environment by the policy makers or government, private sectors and the general public through better institutions will of course provide criteria for peoples' access to environmental resources that in turn can ensure uninterrupted survival of the environment (Ostrom, 2008; Berkes, 2002; Young, 2002). Frankel and Rose (2005) argue that a healthy representative institution significantly reduces environmental degradation, and could even lead to the timely improvement of the environment, and thus speedy turning point of the environmental Kuznets curve. More recent empirical works suggested that improving civil liberty, democracy (Hosseini and Kaneko, 2013) and Rule of law (Castiglione, Infante and Smirnova, 2012) have a positive and significant effect on environmental sustainability across European countries.

There are limited empirical studies which evaluate the role of institutions in promoting pollution mitigation in Africa. However, Bhattarai and Hamming (2001), Culas (2007) and BaliamouneLutz (2012) argue that healthier government policy and political institutions are vital for better environmental quality in Africa even at the early stage of economic development. Certainly, these African studies have provided useful insights concerning the institutional relevance in reducing pollution emissions, they are however limited because of their failure to analyse how financial development or its interaction with institutional quality affect environmental sustainability in the continent. This issue is particularly important for sub-Saharan African countries who, under desperate to achieve higher economic growth may adopt economic policies that compromise environmental sustainability. The effects and significance of financial development and institutional quality on the conservation of the natural environment are therefore issues that deserve more empirical attention, particularly in Africa.

\section{Methodology and Models}

\subsection{Estimation Method}

The majority of studies that investigate the role of FD on environmental sustainability used time series techniques. But existing time series studies are often overwhelmed by collinearity and heteroskedasticity among the explanatory variables (see Hibbs, 1973; Li and Schaub, 2004). Moreover, Beck (2008) argued that when the frequency data is too low, the explanatory power of the time series estimators may be relatively weak. Although among the available works, for example, Tamazian et al. (2009) and Tamazian and Bhaskara Rao (2010) employed panel data specifications of either random effect or generalized-method-of moment (GMM) estimation procedures $^{4}$, however, both the two procedures have important econometric limitations. For example, the random effects model is relatively restrictive because it considers the errors to be time invariant, implying 'strict exogeneity' (Arellano, 2003). The GMM model on the other hand, usually imposes homogeneity restrictions on all slope coefficients as this may lead to wrong policy prescription if the actual slope coefficients of the cross-sectional entities happen to be heterogeneous (see, for example, Pesaran and Shin, 1998).

\footnotetext{
${ }^{4}$ Panel estimators may be more efficient compared to time series procedures, for example, Panel data estimators tend to lessen the collinearity problem (one of the major problem of time series estimates); unlike time series, Panel data can also model how individual entities adjust over time and gives a more precise inference of parameter estimates (Hsiao, 2007).
} 
In addition, though efficient estimates are possible from GMM technique, Roodman (2009) argues that in a case of small sample of cross-sectional units $(\mathrm{N})$ and large time dimension $(\mathrm{T})$, estimates from GMM may likely to produce misleading estimators for the following reasons. First, for small sample observation, the test for autocorrelation (AR) might produce unreliable result; secondly, as the time dimension gets larger, the number of instruments might get larger as well. This would severely affect the validity of Sargan overidentification restrictions test that indicates exogeneity validity of the (generated) instruments. Samargandi, Fidrmuc and Ghosh (2013) furthermore noted that, since GMM are often restricted to the short - time dimension, it only captures short-term dynamics and the stationarity properties of variables are more likely to be ignored. These, therefore, make it doubtful to always rely on the GMM estimator in the context of dynamic panel data specification.

Consequently, to examine the effect of financial development along with institutional quality on the environmental sustainability, we rely on dynamic heterogeneous panel estimation technique introduced by Pesaran, Shin and Smith (1999). More specifically, we employ panel version of the autoregressive distributed lag (ARDL) model that consider two different estimators: the mean group (MG) and pooled mean group (PMG), models. These models have various outstanding features that make them suitable for our study. Unlike the traditional panel models such as the random effects and the GMM dynamic, the PMG methodology as suggested by Pesaran et al. (1999) have advantages since it allows heterogeneous adjustment in the short-run coefficients, error variances and speed of adjustment and, as well impose long run homogenous restrictions on the slope coefficients and thus relatively eliminate the risk of biased estimates. The likelihood that sub-Saharan African countries may share common technology in the long run could be a good reason to consider homogenous long-run coefficients across the region.

Although, as shown by Pesaran and Smith (1995), MG estimator yields consistent estimates of the average long-run coefficients, they however, caution that such estimators will be unreliable and may produce a misleading estimate if the actual slope parameters are homogenous across individual group. Alternatively, Pesaran et al. (1999) suggested PMG estimator that allows for heterogeneity only in the short run. This is better than the traditional panel "... fixed effect estimators and are robust to the presence of unit root and to endogeneity" (Bildirici and Kayikçi, 2013, p. 159).

\subsection{Model Specification}

Following the empirical literature, denoting $L C 2_{i, t}$ the dependent variable, the environmental quality model can be expressed as (see Tamazian and Bhaskara Rao, 2010):

$$
\begin{aligned}
L C 2_{i, t}= & \alpha_{0, i}+\alpha_{1, i} L Y_{i, t}+\alpha_{2, i} L Y_{i, t}^{2}+\alpha_{3, i} L F D_{i, t}+\alpha_{4, i} L I N F_{i, t}+\alpha_{5, i} I_{i, t}+\alpha_{6, i} L F D I_{i, t} \\
& +\alpha_{7, i} L E C_{i, t}+\varepsilon_{i, t}
\end{aligned}
$$

for $\mathrm{i}=1,2, \ldots, \mathrm{N} ; \mathrm{t}=1,2, \ldots, \mathrm{T}$. In Eqn. (1), $C 2$ indicates carbon dioxide emission per capita, $\alpha_{o i}$ represents country-specific intercept, $Y$ and $Y^{2}$ are the real GDP per capita and real GDP per capita squared respectively. In addition, $F D$ is an indicator of financial development (proxies by domestic credit to the private sector as a percentage of GDP), INF is the inflation rate (measured by the consumer price index), and $I Q$ is a measure of the institutional quality (proxies by the quality of a 
country's bureaucracy). FDI denotes net foreign direct investment, and EC indicates energy consumption (proxies by kilogram of energy use per capita of oil equivalent). The subscripts $(i)$ and $(t)$ indicate individual sub-Saharan African country and time, respectively, $\varepsilon$ is the usual error term, $L$ is the logarithm transformation of the variables.

\subsubsection{Panel Integration Analysis}

Before embarking on the dynamic heterogeneous panel estimation, it is appropriate to determine the integration order of our panel data set, that is, whether the variables in our model contain unit root or not. In doing so, we adopt the approach suggested by Im, Pesaran and Shin (IPS, 2003). The choice of IPS can be justified by the nature of our panel dataset which is $\mathrm{N}^{*} \mathrm{~T}$ (balanced panel), as assumed by IPS. The test does not only improve the power of ADF test, it deals with the serial correlation problem. It is also less restrictive, because it allows for heterogeneity of both slope coefficient and intercept across individual units.

The IPS unit root test which allows dynamic panel framework can be specified as follows:

$$
\Delta y_{i, t}=\rho_{i} y_{i, t-1}+\sum_{k=1}^{p_{i}} \theta_{i k} \Delta y_{i, t-k}+\alpha_{i}+\varepsilon_{i, t}
$$

for $\mathrm{i}=1, \ldots, \mathrm{N}$ and $\mathrm{t}=1, \ldots, \mathrm{T}$.

$\mathrm{H}_{\mathrm{o}}: \rho=0$ (each time series in the panel has unit root)

$\mathrm{H}_{\mathrm{a}}: \rho<0$ (allows some to have unit root and, at least one time series is stationary)

This unit root test is based on averaging individual ADF statistics, t-bar, denoted by $t_{\rho_{i}}$. The process involves estimating separate ADF statistics for each unit across the panel followed by computing the average of the individual ADF t-statistics as:

$$
t-b a r=\frac{1}{N} \sum_{i=1}^{N} t_{\rho_{i}}
$$

However, for comparison, this study considers the other unit root tests suggested by Levin, Lin, and Chu (LLC, 2002) and Breitung (2001).

\subsubsection{Dynamic Heterogeneous Panel Specifications}

Equation. (1) can be re-written as

$$
L C 2_{i, t}=\alpha_{0 i}+\beta_{1 i}^{\prime} L X_{i, t}+\varepsilon_{i, t}
$$

Where as specified above, $C 2$ represents a scalar of the environmental quality (the dependent variable), $\mathrm{X}$ represents the $\mathrm{k} \times 1$ vector of other conditional explanatory variables that affect environmental quality in sub-Saharan African countries, $\beta_{i}^{\prime}$ is the $\mathrm{k} x 1$ vector of the coefficients of the explanatory variables, $\alpha_{\mathrm{oi}}$, as specified in equation (1) represents country-specific intercept. 
The group of conditional explanatory variables involved of the other explanatory variables specified in equation (1).

Based on Pesaran et al. (1999) the unrestricted error correction on the basis of ARDL (p, q) for equation (1), can be expressed as follows 5 :

$$
\begin{aligned}
\Delta L C 2_{i, t} & =\lambda_{i} L C 2_{i, t-1}+\delta_{10 i}^{\prime} X_{i, t}+\delta_{11 i}^{\prime} X_{i, t-1}+\varpi_{10 i} L C 2_{i, t}+\varpi_{11 i} L C 2_{i, t-1} \\
& +\beta_{0}+\varepsilon_{i, t}
\end{aligned}
$$

for $\mathrm{i}=1,2, \ldots, \mathrm{N} ; \mathrm{t}=1,2, \ldots, \mathrm{T}$.

The error correction reparamatization of eqn. (4) can be expressed as

$$
\Delta L C 2_{i, t}=\Phi_{i}\left[L C 2_{i, t-1}-\beta_{1 i}^{\prime} L X_{i, t}-\alpha_{0, i}\right]-\delta_{11 i}^{\prime} X_{i, t-1}+\varepsilon_{i, t}
$$

for $\mathrm{i}=1,2, \ldots, \mathrm{N} ; \mathrm{t}=1,2, \ldots, \mathrm{T}$.

Where:

$$
\alpha_{0 i}=\frac{\beta_{0}}{1-\lambda_{i}}, \beta_{1 i}=\frac{\delta_{10 i}^{\prime}+\delta_{11 i}^{\prime}}{1-\lambda_{i}}, \Phi_{i}=-\left(1-\lambda_{i}\right)
$$

The parameter, $\Phi_{\mathrm{i}}$ is the error correction coefficient that measures the speed of adjustment of the environmental quality $L C 2_{i, t}$ towards the long-run equilibrium following change in the conditional explanatory variables. $\beta_{1 i}$, are the long-run parameters while, $\delta_{11 i}^{\prime}$ are the short-run coefficients relating past values of the per capita carbon dioxide emission. As a condition, for the variables to adjust back to the long-run equilibrium from any deviation, $\Phi_{\mathrm{i}}$ is expected to be negative and statistically significant. The significantly negative value of the error correction coefficient indicates cointegration between the environmental quality $L C 2_{i, t}$ variable and its determinants (see Kim, Lin and Suen, 2010).

From equation (1), since per capita income is known to be an essential determinant of economic progress and, also since the quality of the environment is assumed to be a normal good; higher per-capita income would stir higher public demand for cleaner environment. Such rising demand for environmental quality could then lead the government to impose stringent environmental regulations that might stimulate response from local firms via the introduction of environmentally - friendly technologies (Hübler and Keller, 2010; Grossman and Krueger, 1995; Shafik and Bandyopadhya, 1992; e.t.c.). Jalil and Feridun (2011) noted that "the existing studies in the literature generally employ the capital market index as a financial sector indicator" (p. 286). However, since the financial system in SSA is dominated by banks (see Nissanke, 2001), we consider using bank-based financial indicators. Nevertheless, Demetriades and Hussein (1996) argue that credit to the private sector is an appropriate proxy that reflects the ability of the financial system to suitably channel funds to the most productive investment.

\footnotetext{
${ }^{5}$ The optimal lag was selected based on AIC, which is considered more suitable for sample lower than 60 cross-sectional observations (see, Liew, 2004).
} 
Following Tamazian and Bhaskara Rao (2010), we use the inflation rate measured by the consumer price index as a proxy for macroeconomic stability. Our goal is to investigate how the steadiness of macroeconomic indicators in SSA affects environmental quality.

We expect that a higher energy demand can have a positive impact on pollution emissions, due to the relatively lower level of energy efficiency in African countries (Wolde-Rufael, 2009). The inclusion of the institutional quality (bureaucratic quality) index will enable us to examine whether it can be a potential determinant of pollution emissions in SSA. The use of administrative power to gain illicit favours (rent seeking) from economic agents, such as sidestepping formal procedures may lower economic efficiency. Bureaucratic rent-seeking is often associated with inefficiencies in private investment and lower per capita income (see Jaimovich and Rud, 2014). In particular, we argue that the quality of public bureaucracy determines peoples' concern about environmental quality, which in turn affects pollution accumulation. When rent-seeking in the public bureaucracies' lowers income, people will likely be less sensitive to pollution emissions, and as such may be reluctant to mount pressure on the government to improve environmental quality. Moreover, Wang (forthcoming) argues that rent seeking tends to distort the firms' ability to control pollution emissions. There are consistent evidences that show FDI inflows are an important determinant of environmental quality (Cole and Elliot, 2005; Tamazian et al., 2009; Tamazian and Bhaskara Rao, 2010). We include FDI as a control variable to capture the open economy effect of pollution emissions. This is important since carbon dioxide emissions are generally regarded as a global pollutant (see, for example, Ibrahim and Law, 2014; Baiocchi and Minx, 2010). In addition, Rajan and Zingales (2003) noted that the decisions of countries to open for foreign capital inflows may have a political influence. Thus, the effect of FDI on the environment could be conditional on the political bureaucracy. Because of this, it is important that we examine the joint effect of foreign direct investment and bureaucratic quality. We do this by including their interaction term.

\section{Data Sources}

The analysis of this study makes use of macro panel data set of 13 selected sub-Saharan African countries in the period $1984-2013$. The start period is dictated based on the data availability of the bureaucratic quality for relatively longer period, while the end period is based on the availability of energy consumption data. Data on per capita Carbon dioxide emissions, aggregate FDI measured in Net inflows of FDI as a Share of GDP, energy consumption measured in kilogram of energy use per capita of oil equivalent and real per capita income (real GDP) in constant 2005 US dollars, which is used as a measure of the level of economic progress or development, inflation rate measured by the consumer price index, the financial development indicator measured by the domestic credit to the private sector are all taken from the online World Bank's world development indicators $(2014)^{6}$.The index for bureaucratic quality, which is measured on a scale of 0 to 4 , where, for example, a higher score indicates policies stability of the government irrespective of regime change. This index, characterized by political risk rating is constructed by the International Country Risk Guide (ICRG, 2013). The 13 countries in this study are selected based on the

\footnotetext{
${ }^{6}$ The net FDI inflows for some countries contain a few negative values, and based on Osborne (2002), we add a constant value to the data so as to move the minimum value of the observation above zero before applying the log transformation. On the other hand, we also observed that the data for domestic credit to the private sector for South Africa (1991) and Zambia (1992) were missing, and we used linear interpolation to fill them.
} 
availability of all the data required for the analysis. The list of sample countries considered are presented in table Appendix A.

\section{Empirical Findings}

The panel unit root test results are presented in table 1. To allow for representation of alternative hypotheses, both constant terms and time trends are included in the tests. The measure of environmental quality (LC2), the variables of income growth (LY, LY2), the financial development indicator (LFD), the institutional quality index (IQ) and all the conditional control variables (LFDI, LINF, LEC) are tested for the unit root both in levels and in first differences. As can be observed from this table, the panel unit roots tests for IPS, except for income, financial development indicator, institutional quality index and energy consumption, all the remaining variables are found to be stationary at their levels. While for LLC, only carbon dioxide emissions, income, foreign direct investment, and inflation rate exhibit stationarity at levels.

Whereas using Breitung panel unit root tests, only income, financial development indicator and energy consumption variables exhibit unit root properties at levels. But, when the unit root test was conducted for the whole variables at their first difference, all the three tests support the hypothesis of stationarity property in all the variables across the countries considered at the 1 percent level of significance. Therefore, our series are characterized as an I (0) and I(1) process and thus allow us to apply the PMG and the MG estimation techniques.

Table 1: Panel Unit Root Tests

\begin{tabular}{|c|c|c|c|c|c|c|}
\hline & \multicolumn{3}{|c|}{ Levels } & \multicolumn{3}{|c|}{ First difference } \\
\hline & $\begin{array}{l}\text { Im, Pesaran } \\
\text { and Shin (IPS) }\end{array}$ & $\begin{array}{l}\text { Levin, Lin, and } \\
\text { Chu (LLC) }\end{array}$ & Breitung & $\begin{array}{l}\text { Im, Pesaran } \\
\text { and Shin }\end{array}$ & $\begin{array}{l}\text { Levin, Lin, } \\
\text { Chu } \\
\text { (LLC) }\end{array}$ & Breitung \\
\hline LC2 & $-2.72 * * *$ & $-2.29 * *$ & $-1.74 * *$ & $-15.54 * * *$ & $-14.15 * * *$ & $-4.93 * * *$ \\
\hline LY & .980 & $-1.46 * *$ & 3.20 & $-7.33 * * *$ & $-6.99 * * *$ & $-4.16 * * *$ \\
\hline LFD & .790 & 1.14 & .779 & $-12.51 * * *$ & $-11.87 * * *$ & $-7.89 * * *$ \\
\hline LFDI & $-7.34 * * *$ & $-6.06 * * *$ & $-5.91 * * *$ & $-16.30 * * *$ & $-14.35 * * *$ & $-5.73 * * *$ \\
\hline LINF & $-5.15 * * *$ & $-6.38 * * *$ & $-6.09 * * *$ & $-12.27 * * *$ & $-12.02 * * *$ & $-7.14 * * *$ \\
\hline IQ & -.697 & 1.55 & $-2.70 * * *$ & $-7.23 * * *$ & $-3.09 * * *$ & $-5.84 * * *$ \\
\hline LEC & .670 & -1.17 & 1.65 & $-15.45 * * *$ & $-17.09 * * *$ & $-7.22 * * *$ \\
\hline
\end{tabular}

Notes: $* *$ and $* * *$ indicate significance at $5 \%$ and $1 \%$ levels, respectively, which Signifies rejection of the unit root hypothesis. Optimum lag lengths are selected based on Akaike information criterion (AIC).

Tables 2 and 3 present estimated results of PMG and MG. First, we discuss the results for the baseline equation (1) (see Table 2; model 1). Then we check whether interacting FDI and bureaucratic quality would affect the FDI-induced environmental effect (see Table 2; model2 and Table 3 models 3 \& 4). Table 3 presents seperate regression including the indictor for macroeconmic stabilty (the inflation rate). Table 4 reports results for both inflation rate and capital account openness. Beginning the analysis with our baseline model (model 1, table 2), we note that the Hausman test validates long run homogeneity restriction across the selected sub-Saharan African countries, which indicate that PMG estimator is more efficient than the MG. For this 
reason our discussion will only focus on the PMG estimates. The efficiency of the PMG estimator over MG's might suggest homogenous long-run relationships between carbon dioxide emissions, financial development, institutional quality and other control variables across the sample countries.

Table 2: Results of $\mathrm{CO}_{2}$ equation function, $\operatorname{ARDL}(1,1,1,1,1,1,1)$

\begin{tabular}{|c|c|c|c|c|}
\hline \multirow[t]{2}{*}{ Variables } & \multicolumn{2}{|c|}{ Model-1 } & \multicolumn{2}{|c|}{ Model-2 } \\
\hline & PMG & MG & PMG & $\mathrm{MG}$ \\
\hline Constant & $\begin{array}{l}-7.14 * * * \\
(-5.45)\end{array}$ & $\begin{array}{l}-450.59 \\
(-1.41)\end{array}$ & $\begin{array}{l}-6.88 * * * \\
(-5.14)\end{array}$ & $\begin{array}{l}-1039.84 \\
(-1.19)\end{array}$ \\
\hline Convergence coefficient & $-.47 * * *$ & $-.77 * *$ & $-.46 * * *$ & $-.78 * * *$ \\
\hline \multicolumn{5}{|l|}{ Long run coefficient } \\
\hline LY & $\begin{array}{l}2.01 * * * \\
(2.83)\end{array}$ & $\begin{array}{l}176.01 \\
(1.27)\end{array}$ & $\begin{array}{l}1.96^{* * * *} \\
(2.81)\end{array}$ & $\begin{array}{l}330.79 \\
(1.36)\end{array}$ \\
\hline LY2 & $\begin{array}{l}-.120 * * * \\
(-2.77)\end{array}$ & $\begin{array}{l}-12.72 \\
(-1.20)\end{array}$ & $\begin{array}{l}-.117 * * * \\
(-2.74)\end{array}$ & $\begin{array}{l}-21.65^{*} \\
(-1.40)\end{array}$ \\
\hline LFD & $\begin{array}{l}.044 * * \\
(2.15)\end{array}$ & $\begin{array}{l}.145 \\
(.46)\end{array}$ & $\begin{array}{l}.053 * * \\
(2.44)\end{array}$ & $\begin{array}{l}.093 \\
(.30)\end{array}$ \\
\hline LFDI & $\begin{array}{l}-153 * * * \\
(-3.27)\end{array}$ & $\begin{array}{l}-.098 \\
(-.35)\end{array}$ & $\begin{array}{l}.178 * * * \\
(-3.82)\end{array}$ & $\begin{array}{l}2.51 \\
(1.53)\end{array}$ \\
\hline IQ & $\begin{array}{l}.032 * * * \\
(4.95)\end{array}$ & $\begin{array}{l}-.044 \\
(-.48)\end{array}$ & $\begin{array}{l}.028 * * * \\
(3.25)\end{array}$ & $\begin{array}{l}.177 \\
. .57)\end{array}$ \\
\hline LFDI*IQ & & & $\begin{array}{l}-.032 \\
(-.61)\end{array}$ & $\begin{array}{l}2.27 \\
(1.31)\end{array}$ \\
\hline LEC & $\begin{array}{l}1.10 * * * \\
(11.45)\end{array}$ & $\begin{array}{l}2.64 * * \\
(2.20)\end{array}$ & $\begin{array}{l}1.08 * * * \\
(11.23)\end{array}$ & $\begin{array}{l}2.26 \\
(1.53) \\
\end{array}$ \\
\hline \multicolumn{5}{|l|}{ Short run coefficient } \\
\hline$\Delta \mathbf{L Y}$ & $\begin{array}{l}86.13 \\
(.77)\end{array}$ & $\begin{array}{l}30.53 \\
(-.46)\end{array}$ & $\begin{array}{l}92.64 \\
(.80)\end{array}$ & $\begin{array}{l}-7.74 \\
(-.09)\end{array}$ \\
\hline$\Delta \mathrm{LY2}$ & $\begin{array}{l}-4.51 \\
(-.70)\end{array}$ & $\begin{array}{l}3.18 \\
(.68)\end{array}$ & $\begin{array}{l}-4.88 \\
(-.73)\end{array}$ & $\begin{array}{l}1.85 \\
(.31)\end{array}$ \\
\hline$\Delta$ LFD & $\begin{array}{l}-.077 \\
(-.94)\end{array}$ & $\begin{array}{l}.005 \\
(.03)\end{array}$ & $\begin{array}{l}-.070 \\
(-.81)\end{array}$ & $\begin{array}{l}.089 \\
(.47)\end{array}$ \\
\hline$\Delta$ LFDI & $\begin{array}{l}.044 \\
(.58)\end{array}$ & $\begin{array}{l}.044 \\
(.59)\end{array}$ & $\begin{array}{l}.162 \\
(1.60)\end{array}$ & $\begin{array}{l}-1.26 \\
(-1.10)\end{array}$ \\
\hline$\Delta \mathrm{IQ}$ & $\begin{array}{l}-.088 \\
(-1.01)\end{array}$ & $\begin{array}{l}-.020 \\
(-.20)\end{array}$ & $\begin{array}{l}-.075 \\
(-.84)\end{array}$ & $\begin{array}{l}-.147 \\
(-.85)\end{array}$ \\
\hline$\Delta$ LFDI*IQ & & & $\begin{array}{l}.075 \\
(.80)\end{array}$ & $\begin{array}{l}-1.40 \\
(-1.21)\end{array}$ \\
\hline$\Delta \mathrm{LEC}$ & $\begin{array}{l}1.22 \\
(1.64)\end{array}$ & $\begin{array}{l}-.217 \\
(-.31)\end{array}$ & $\begin{array}{l}1.22 \\
(1.60)\end{array}$ & $\begin{array}{l}-.409 \\
(-.50)\end{array}$ \\
\hline No. of countries & 13 & 13 & 13 & 13 \\
\hline No. of Obs & 338 & & 338 & \\
\hline Hausman tests & $5.30(.51)$ & & $2.31(.94)$ & \\
\hline Log Likelihood & 290.01 & & 296.48 & \\
\hline
\end{tabular}


Notes: *Statistically significant at $10 \%$. **Statistically significant at $5 \%$. ***Statistically significant at $1 \%$. AIC criterion is used to choose the lag order. Figures in brackets are t-statistics. As shown in model 1, table 2, the error correction term or the speed of adjustment is correctly signed and strongly significant. This suggests the dynamic long run stability of the estimated PMG model. Moreover, this shows long-run cointegration relationships between $\mathrm{CO}_{2}$ emissions and its explanatory variables (in equation 1) and clear evidence of non-spurious convergence from any deviation from the long-run equilibrium. $\mathrm{CO}_{2}$ emissions adjust at the speed about $47 \%$ or it will take SSA about 2 years and 2 months to reach equilibrium when there is any deviation from the long-run.

In support of the EKC hypothesis, the per capita GDP and the per capita GDP square are found to be significantly positive and negative respectively. For every $1 \%$ increase in the per capita output, per capita carbon dioxide emissions are increasing by $2.01 \%$, while the same percent point increase in per capita GDP square makes pollution to fall by .12\%. Both the key variables of interest, financial development indicator and the institutional quality index are found to be significant determinants of carbon dioxide in the selected countries. In the case of FD, we confirm the result of Zhang (2011) who find a similar result in his time series study and provide evidence against Tamazian, Chausa and Vadlamannati (2009), Tamazian and Bhakara Rao (2010), Jalil and Feridun (2011), Shabaz, Hye, Tiwari and Leitao (2013) and Shabaz, Tiwari and Nasir (2013) among others. The parameter estimate of the institutional quality suggests that an improvement in the bureaucratic quality could lead to a decline in $\mathrm{CO}_{2}$ emissions in the sub-Saharan African region. The estimated coefficient on the FDI inflow turns out to be negative and strongly significant in explaining the environmental quality across the SSA region. The estimated elasticity indicates that a one point percent increase in the net foreign direct investment will lead to about .153 percent reduction in carbon dioxide emissions. Perhaps a better share of this elasticity emanates through its technology spillover effect. The estimated coefficient on energy consumption is positive and significant at the $1 \%$ level. Hence, energy consumption turns out to be an important determinant of environmental damage across the countries examined.

Column 3 and 4 of table 2 (model 2), repeats model 1, entering the institutional quality and FDI inflows interactively as a pollution determinant across sub-Saharan African countries ${ }^{7}$. This is to check whether the institutional quality that negatively affects environmental quality will have a potential indirect influence on the FDI- pollution nexus. Specifically, if the coefficient on the interaction term is found significant, is an indication that the marginal effect of FDI on the environment is contingent on the political bureaucracy. The Hausman test results in model 2 revealed again that PMG estimator is more consistent and efficient than the MG estimator. Again,

\footnotetext{
${ }^{7}$ It is noteworthy that including the interaction term (FDI*IQ) may lead to multicollinearity as it may be perfectly collinear with the constitutive terms, that is, FDI and the bureaucratic quality, and omitting either or both of them may lead to bias estimate(s) or omitted variable(s) bias (see Brambor, Clark and Golder, 2006). To address this issue, we orthogonalised the interaction term (i.e. the residual obtained) from the regression of the cross-product of FDI and institutional quality using the two-step procedure suggested by Burrill (2006). DiLalla and Mullineaux (2008) further note that the interaction term obtained through this method does not depend on the constitutive terms, thus not violating the standard assumption of independence of the explanatory variables.
} 
both per capita income variables estimated can be seen to be 'correctly' signed, similar in term of significance to those reported in model 1 (although, with slightly lower magnitudes). This therefore confirms the presence of an EKC across the study countries. We note that entering the interaction of foreign direct capital inflows and the bureaucratic quality in model 2 does not change the impacts of domestic credit to private sector and the bureaucratic quality have on the environment across the region. Specifically, both the variables maintain positive and statistically significant coefficients at $5 \%$ and $1 \%$ levels, respectively, however, the interaction term appears not to be significantly different from zero. This seems to suggest the sustainability effect of FDI on the environment is not likely to be contingent on the political bureaucracy. Note that the energy consumption variable still has a strong positive effect on pollution emissions. This is perhaps not surprising because of the relatively low energy efficiency across the continent ${ }^{8}$.

Table 3: Results of $\mathrm{CO}_{2}$ equation function, $\operatorname{ARDL}(1,1,1,1,1,1,1,1)$

\begin{tabular}{|c|c|c|}
\hline \multirow[t]{2}{*}{ Variables } & \multicolumn{2}{|c|}{ Model-3 } \\
\hline & PMG & $\mathrm{MG}$ \\
\hline Constant & $\begin{array}{l}-6.73 * * * \\
(-5.24)\end{array}$ & $\begin{array}{l}-1888.89 \\
(-1.24)\end{array}$ \\
\hline Convergence coefficient & $-.45 * * *$ & $-.96 * * *$ \\
\hline \multicolumn{3}{|l|}{ Long run coefficient } \\
\hline LY & $\begin{array}{l}1.93 * * \\
(2.56)\end{array}$ & $\begin{array}{l}444.89 \\
(1.40)\end{array}$ \\
\hline LY2 & $\begin{array}{l}-.12 * * \\
(-2.50)\end{array}$ & $\begin{array}{l}-27.86 \\
(-1.48)\end{array}$ \\
\hline LFD & $\begin{array}{l}.061 * * \\
(2.51)\end{array}$ & $\begin{array}{l}.072 \\
(.23)\end{array}$ \\
\hline LFDI & $\begin{array}{l}-.189 * * * \\
(-3.90)\end{array}$ & $\begin{array}{l}1.70 \\
(1.47)\end{array}$ \\
\hline IQ & $\begin{array}{l}.028 * * * \\
(3.01)\end{array}$ & $\begin{array}{l}.125 \\
(.58)\end{array}$ \\
\hline LFDI*IQ & $\begin{array}{l}.010 \\
(-.19)\end{array}$ & $\begin{array}{l}1.74 \\
(1.47)\end{array}$ \\
\hline LEC & $\begin{array}{l}1.091 * * * \\
(10.76)\end{array}$ & $\begin{array}{l}2.65 * \\
(1.89)\end{array}$ \\
\hline LINF & $\begin{array}{l}.020 \\
(.49)\end{array}$ & $\begin{array}{l}.240 * * \\
(2.09)\end{array}$ \\
\hline \multicolumn{3}{|l|}{ Short run coefficient } \\
\hline$\Delta \mathbf{L Y}$ & $\begin{array}{l}100.75 \\
(.89)\end{array}$ & $\begin{array}{l}-144.50 * * \\
(-2.03)\end{array}$ \\
\hline$\Delta \mathrm{LY2}$ & $\begin{array}{l}-5.52 \\
(-.85)\end{array}$ & $\begin{array}{l}10.79 \\
(1.95)\end{array}$ \\
\hline$\Delta$ LFD & $\begin{array}{l}-.071 \\
(-.80)\end{array}$ & $\begin{array}{l}.132 \\
(.59)\end{array}$ \\
\hline SLFDI & $\begin{array}{l}.180 \\
(1.53)\end{array}$ & $\begin{array}{l}-1.19 \\
(-1.08)\end{array}$ \\
\hline
\end{tabular}

${ }^{8}$ See, for example, Wolde-Rufael (2005) 


\begin{tabular}{|l|l|l|}
\hline$\Delta$ IQ & -.059 & -.082 \\
& $(.480)$ & $(-.50)$ \\
\hline$\Delta$ LFDI*IQ & -.68 & -1.48 \\
& $(.719)$ & $(-1.36)$ \\
\hline$\Delta$ LEC & $.1 .28^{*}$ & -.897 \\
& $(1.86)$ & $(-1.02)$ \\
\hline$\Delta$ LINF & .003 & $-.173^{* * *}$ \\
& $(.11)$ & $(-2.67)$ \\
\hline No. of countries & 13 & 13 \\
\hline No. of Obs & 338 & \\
\hline Hausman tests & $4.41(.819)$ & \\
\hline Log Likelihood & 302.51 & \\
\hline
\end{tabular}

Notes: *Statistically significant at $10 \%$. **Statistically significant at $5 \%$. ***

Statistically significant at $1 \%$. AIC criterion is used to choose the lag order.

Figures in brackets are t-statistics.

Turning to table 3 , where we examine the environmental sustainability effect of a measure of macroeconomic stability. It is noteworthy in this regression (see table 3, model 3), that the Hausman test validates the efficiency of PMG estimates as compared to MG estimates. We also note that the effect of macroeconomic stability did not appear to be statistically significant in explaining greenhouse gases across the region, while the per capita income variables retain their expected signs and become significant at the 5\% level (although, with lower significance levels). Moreover, we also note that financial development indicator, institutional quality, FDI, energy consumption and the interaction term of FDI and bureaucratic quality appear to be qualitatively similar to those reported in table2, table 2 .

It is worth noting that, although, an inverted U-relationship between per capita income and environmental quality is strongly supported by the evidences in all the models reported in tables 2 $\& 3$, however, without a proper test for the existence of the inverted $\mathrm{U}$, our interpretation could be misleading. This suggests that the interpretation of our results of the non-linearity associated with the EKC in these models should be made with caution.

Accordingly, the rest of our analysis focuses on testing empirically the geneunity of an inverted $U$ shape reported in tables $2 \& 3$ as predicted by the composite null hypothesis that the relationship between per capita income and the environment is increasing at the left hand side of the interval and/or is decreasing at the right hand side (i.e. The EKC hypothesis). To do this, we use the test proposed by Lind and Mehlum (2010), which is based on the likelihood ratio test framework developed by Sasabuchi (1980). We also use the Fieller (1954) method to compute the confidence interval for the estimated extreme point, as suggested by Lind and Mehlum.

Table 4: Test of an inverse U-shaped relationship between per capita income and the environment

\begin{tabular}{|l|l|l|l|}
\hline \multirow{2}{*}{ Variables } & \multicolumn{1}{|c|}{ Model-1 } & \multicolumn{1}{c|}{ Model-2 } & \multicolumn{1}{c|}{ Model-3 } \\
\cline { 2 - 4 } & PMG & PMG & PMG \\
\hline LY & $2.01^{* * *}$ & $1.96^{* * *}$ & $1.93^{* *}$ \\
\hline
\end{tabular}




\begin{tabular}{|l|l|l|l|}
\hline & $(2.83)$ & $(2.81)$ & $(2.56)$ \\
\hline LY2 & $-.120^{* * *}$ & $-.117^{* * *}$ & $-.12^{* *}$ \\
& $(-2.77)$ & $(-2.74)$ & $(-2.50)$ \\
\hline Upper bound & $34.89^{* * *}$ & $34.89^{* * *}$ & $31.06^{* * *}$ \\
& $(3.23)$ & $(3.23)$ & $(2.86)$ \\
\hline Lower bound & $-9.25^{* * *}$ & $-9.25^{* * *}$ & $-8.20^{* * *}$ \\
& $(-3.22)$ & $(-3.22)$ & $(-2.84)$ \\
\hline Sasabuchi-test of inverted U-shape & 3.22 & 3.22 & 2.84 \\
& {$[.002]$} & $(.002)$ & {$[.005]$} \\
\hline Estimate extreme Point & 6.44 & 6.44 & 6.44 \\
\hline 99\% confidence of Fieller interval & {$[5.767,9.001]$} & {$[5.767,9.001]$} & {$[5.767,9.001]$} \\
\hline
\end{tabular}

Notes: **Statistically significant at $5 \%$. ***Statistically significant at $1 \%$. P-values in Square brackets

Table 4 reports the results of testing the presence of an inverted U Shape relationship between per capita income and environmental quality in the SSA region. As can be seen in models 1-3 of table 4 , using the classical method, the t-values of the per capita income coefficients range from 2.50 to 2.83. However, with the appropriate inverted $U$ test, we observe that the test for positive slopes yield one sided t-values ranging from 2.84 to 3.22 across the three models, and are significant at the $1 \%$ level. The evidences from these tests thus provide support for the presence of an inverted U-shaped relationship between per capita income and environment across the sample countries.

\section{Conclusions}

The analysis of this study draws on the new developments that postulate the role of financial development and institutional quality on the income-environment nexus. Empirical investigation of environmental impact of financial development has been stimulating an emergent attention with opposing submissions.

This study contributes to the emerging set of empirical works on the role of financial development and institutional quality in the income-environment relationship. The central thesis that environmental quality worsen with per capita output, but then improve at higher per capita output growth is strongly supported through the empirical results presented in this study, thus confirming the EKC hypothesis. Moreover, the approriate inverted U shape test results presented in this paper strengthened this hypothesis, and also suggest that most works that claimed the presence of EKC in Africa seem to be fairly reliable. Our results also showed that the effect of FDI inflows is to reduce carbon dioxide emissions, and this effect seems hardly affected by political bureaucracy. However, we find that improved bureaucratic quality will help to reduce carbon dioxide emissions. While the majority of the existing evidence finds that financial development is good for the better performance of the environment, we show that financial development is negatively related to environmental sustainability across the sub-Saharan African countries. But the proposition that it is hard to achieve robust economic progress with sustained environmental quality when indigenous institutions are weak is strongly supported. Our results also showed that energy consumption has a positive scale effect of environmental damage in SSA. 
Finally, enhancing indigenous institutions, particularly, bureaucratic reform that limits administrative bottleneck and/or rent-seeking will probably have a significant positive impact on the environmental conservation across the region. Furthermore, evidence presented in this research indicates the need to improve financial services that can promote guaranteed access to clean technology and renewable energy needed to contain the increase of environmental challenges in the region.

\section{Appendix A}

Table A1: List of sample countries

\begin{tabular}{|l|l|}
\hline Botswana & Nigeria \\
\hline Cameroon & Senegal \\
\hline Congo, Rep. & South Africa \\
\hline Cote d'Ivoire & Sudan \\
\hline Gabon & Togo \\
\hline Ghana & Zambia \\
\hline Kenya & \\
\hline
\end{tabular}

\section{Appendix B}

Table B1: Variables definition

\begin{tabular}{|l|l|l|l|}
\hline Variables & Definition & Unit measurement & Source \\
\hline CO2 & $\begin{array}{l}\text { Environmental quality: } \\
\text { Emissions of CO2 }\end{array}$ & $\mathrm{CO}_{2}$ (Metric tons per capita) & $\begin{array}{l}\text { World Bank } \\
\text { (Online, 2014) }\end{array}$ \\
\hline $\mathbf{Y}$ & $\begin{array}{l}\text { Per capita income } \\
\text { (measured by real GDP) }\end{array}$ & Constant 2000 US dollars & $\begin{array}{l}\text { World Bank } \\
\text { (Online, 2014) }\end{array}$ \\
\hline FD & Financial development & Domestic credit to Private sector & $\begin{array}{l}\text { World Bank } \\
\text { (Online, 2014) }\end{array}$ \\
\hline FDI & Foreign direct investment & $\begin{array}{l}\text { Net inflows of FDI as a Share of } \\
\text { GDP }\end{array}$ & $\begin{array}{l}\text { World Bank } \\
\text { (Online, 2014) }\end{array}$ \\
\hline EC & Energy consumption & $\begin{array}{l}\text { Kilogram of energy use per } \\
\text { capita of oil equivalent }\end{array}$ & $\begin{array}{l}\text { World Bank } \\
\text { (Online, 2014) }\end{array}$ \\
\hline IQ & Inflation rate & $\begin{array}{l}\text { A measure of macroeconomic } \\
\text { stability }\end{array}$ & $\begin{array}{l}\text { World Bank } \\
\text { (Online, 2014) }\end{array}$ \\
\hline
\end{tabular}

\section{Appendix C}

Table C1: Descriptive statistics: Annual panel -1984-2013

\begin{tabular}{|l|l|l|l|l|l|}
\hline & Mean & Minimum & Maximum & Standard deviation & Observation \\
\hline LC2 & -.60 & -2.94 & 2.34 & 1.15 & 351 \\
\hline LY & 7 & 5.77 & 9.00 & .95 & 351 \\
\hline LY & 49.93 & 33.26 & 81.01 & 14 & 351 \\
\hline LFD & 2.72 & .48 & 5.12 & .87 & 351 \\
\hline
\end{tabular}




\begin{tabular}{|l|l|l|l|l|l|}
\hline LFDI & 2.39 & -.89 & 3.70 & .34 & 351 \\
\hline LINF & 3.09 & -.21 & 5.28 & .60 & 351 \\
\hline IQ & 1.68 & 0 & 4 & 1.01 & 351 \\
\hline LEC & 6.32 & 5.34 & 7.99 & .65 & 351 \\
\hline
\end{tabular}

Notes: All the variables are as defined in section 3.

\section{Appendix D}

Table D1 presents correlation coefficients between the environmental quality measure and the measures of its determinants. The only notable high correlations are those of carbon dioxide emissions with per capita income variables, and as well with energy consumption. There is also a high correlation between energy consumption and the per capita income variables. Other noteworthy, though low, is the negative correlations of carbon dioxide emissions, income and financial development with FDI. Although, the negative correlation between economic growth and FDI may be surprising, it might however, reflect the state of bureaucratic quality in the region. Other notable negative correlations are those between inflation (a proxy for macroeconomic stability) with $\mathrm{CO}_{2}$ emissions, income and financial development indicator, and a negative correlation between bureaucratic quality and FDI inflows across the sample countries.

Table D1: Correlations for $\mathrm{CO}_{2}$ and its determinants

\begin{tabular}{|l|l|l|l|l|l|l|l|l|}
\hline & LC2 & LY & LY $^{2}$ & LFD & LFDI & LINF & IQ & LEC \\
\hline LC2 & 1 & & & & & & & \\
\hline LY & .84 & 1 & & & & & & \\
\hline LY $^{2}$ & .85 & .99 & 1 & & & & & \\
\hline LFD & .56 & .31 & .31 & 1 & & & & \\
\hline LFDI & -.19 & -.15 & .16 & -.18 & 1 & & & \\
\hline LINF & -.18 & -.31 & .31 & -.29 & .07 & 1 & & \\
\hline IQ & .49 & .41 & .41 & .40 & -.27 & -.06 & 1 & \\
\hline LEC & .82 & .72 & .74 & .45 & -.15 & .03 & .38 & 1 \\
\hline
\end{tabular}

Notes: All the variables are as defined in section 3.

\section{References}

[1] ABU-BADER, S. and ABU-QARN, A.S. (2008). Financial development and economic growth: The Egyptian experience. Journal of Policy Modeling, 30, 887-898.

[2] ANTWEILER, W., COPELAND, B. R. and TAYLOR, M. S. (2001). Is Free Trade Good for the Environment?. American Economic Review, 91(4), 877-908.

[3] ARELlANO, M. (2003). Discrete choices with panel data. Investigaciones Económicas, 27(3), 423-458.

[4] BAIOCCHI, G. and MINX, J. C. (2010). Understanding changes in the UK's CO2 emissions: A global perspective. Environmental science and technology, 44(4), 1177-1184.

[5] BALIAMOUNE-LUTZ, M. (2012). Trade and Environmental Quality in African Countries: Do Institutions Matter? (No. 14-2012). ICER-International Centre for Economic Research.

[6] BECK, T. (2008). The econometrics of finance and growth (No. 4608). The World Bank.

[7] BERKES, F. (2002). Cross-scale institutional linkages: perspectives from the Bottom up. The Drama of the commons, 293-321. 
[8] BHATTARAI, M. and HAMMIG, M. (2001). Institutions and the environmental Kuznets curve for deforestation: a cross-country analysis for Latin America, Africa and Asia. World development, 29(6), 995-1010.

[9] BILDIRICI, M. E. and KAYIKÇI, F. (2013). Effects of oil production on economic growth in Eurasian countries: Panel ARDL approach. Energy, 49, 156-161.

[10] BRAMBOR, T., CLARK, W. R. and GOLDER, M. (2006). Understanding interaction models: Improving empirical analyses. Political analysis, 14(1), 63-82.

[11] BREITUNG, J. (2001). The local power of some unit root tests for panel data (Vol. 15, pp. 161177). Emerald Group Publishing Limited.

[12] BURRILL, D. F. (2006). Modeling and interpreting interactions in multiple regression. available at http://www.minitab.com/uploadedFiles/Content/News/Published_Articles/

[13] interactions_in_multiple_regression.pd (Accessed 26 January, 2015).

[14] CAGATAY, S. and MIHCI, H. (2006). Degree of environmental stringency and the impact on trade patterns. Journal of economic studies, 33(1), 30-51.

[15] CASTIGLIONE, C., INFANTE, D. and SMIRNOVA, J. (2012). Rule of law and the Environmental Kuznets Curve: evidence for carbon emissions. International Journal of Sustainable Economy, 4(3), 254-269.

[16] COLE, M. A. and ELLIOTT, R. J. (2003). Determining the trade-environment composition effect: the role of capital, labor and environmental regulations. Journal of Environmental Economics and Management, 46(3), 363-383.

[17] COLE, M. A. and ELLIOTT, R. J. (2005). FDI and the capital intensity of "dirty" sectors: a missing piece of the pollution haven puzzle. Review of Development Economics, 9(4), 530-548.

[18] COLE, M. A. and NEUMAYER, E. (2004). Examining the impact of demographic factors on air pollution. Population and Environment, 26(1), 5-21.

[19] CULAS, R.J. (2007). Deforestation and the environmental Kuznets curve: an institutional perspective.Ecological economics, 61, 429-437.

[20] DE GREGORIO, J. and GUIDOTTI, P. E. (1995). Financial development and economic growth. World development, 23(3), 433-448.

[21] DE LONGUEVILLE, F., HOUNTONDJI, Y. C., HENRY, S. and OZER, P. (2010). What do we know about effects of desert dust on air quality and human health in West Africa compared to other regions?. Science of the total environment, 409(1), 1-8.

[22] DEMETRIADES, P. O. and HUSSEIN, K. A. (1996). Does financial development cause economic growth? Time-series evidence from 16 countries. Journal of development Economics, 51(2), 387411.

[23] DilAllA, L. F. and MULlinEAUX, P. Y. (2008). The effect of classroom environment on problem behaviours: A twin study. Journal of school psychology, 46(2), 107-128.

[24] FRANKEL, J. A. and ROSE, A. K. (2005). Is trade good or bad for the environment? Sorting out the causality. Review of Economics and Statistics, 87(1), 85-91.

[25] FREEMAN, R. B. (1994). Crime and the Job Market (No. 4910). National Bureau of Economic Research, Inc.

[26] GOLDSMITH, R.W. (1969). Financial Structure and Development, New Haven: Yale University Press.

[27] GROSSMAN, G. M. and KRUEGER, A. B. (1991). Environmental impacts of a North American free trade agreement (No. w3914). National Bureau of Economic Research.

[28] GROSSMAN, G. M. and KRUEGER, A. B. (1995). Economic growth and the environment. The quarterly journal of economics, 110(2), 353-377.

[29] HIBBS JR, D. A. (1973). Problems of statistical estimation and causal inference in time-series regression models. Sociological methodology, 1974, 252-308.

[30] HITAM, M. B. and BORHAN, H. B. (2012). FDI, growth and the environment: impact on quality of life in Malaysia. Procedia-Social and Behavioral Sciences, 50, 333-342. 
[31] HOSSEINI, H.M. and KANEKO, S. (2013). Can environmental quality spread through institutions?. Energy policy, 56, 312-321.

[32] Hsiao, C. (2007). Panel data analysis - advantages and challenges. Test,16(1), 1-22.

[33] HÜBLER, M. and KELLER, A. (2010). Energy savings via FDI? Empirical evidence from developing countries. Environment and Development economics, 15(1), 59.

[34] IBRAHIM, M. H. and LAW, S. H. (2014). Social capital and $\mathrm{CO}_{2}$ emission-output relations: A panel analysis. Renewable and Sustainable Energy Reviews, 29, 528-534.

[35] IM, K. S., PESARAN, M. H. and SHIN, Y. (2003). Testing for unit roots in heterogeneous panels. Journal of econometrics, 115(1), 53-74.

[36] JAIMOVICH, E. and RUD, J. P. (2014). Excessive public employment and rent-seeking traps. Journal of Development Economics, 106, 144-155.

[37] JALIL, A. and FERIDUN, M. (2011). The impact of growth, energy and financial development on the environment in China: A cointegration analysis. Energy Economics, 33 (2), 284-291.

[38] KARL, T. L. (2007). Oil-led development: social, political, and economic consequences. Encyclopedia of energy, 4, 661-672.

[39] KARP, L. (2011). The environment and trade. Annu. Rev. Resour. Econ., 3(1), 397-417.

[40] KHANNA, N. and PLASSMANN, F. (2004). The demand for environmental quality and the environmental Kuznets Curve hypothesis. Ecological Economics, 51(3), 225-236.

[41] KIM, D. H., LIN, S. C. and SUEN, Y. B. (2010). Dynamic effects of trade openness on financial development. Economic Modelling, 27(1), 254-261.

[42] KING, R. G. and LEVINE, R. (1993). Finance and Growth: Schumpeter Might be Right. The Quarterly Journal of Economics, 108(3), 717-737.

[43] LEVIN, A., LIN, C. F. and JAMES CHU, C. S. (2002). Unit root tests in panel data: asymptotic and finite-sample properties. Journal of econometrics, 108(1), 1-24.

[44] LI, Q. and SCHAUB, D. (2004). Economic Globalization and Transnational Terrorism A Pooled Time-Series Analysis. Journal of Conflict Resolution, 48(2), 230-258.

[45] LIEB, C.M. (2003). The Environmental Kuznets Curve: A Survey of the Empirical Evidence and of Possible Causes'. University of Heidelberg, Department of Economics, Discussion Paper No. 391. Available at http://www.uni-heidelberg.de=institute=fak18=awi=index d. Html

[46] LIEW, V. K. S. (2004). Which lag length selection criteria should we employ? Economics Bulletin, 3(33), 1-9.

[47] LIND, J. T. and MEHLUM, H. (2010). With or Without U? The Appropriate Test for a U-Shaped Relationship*. Oxford Bulletin of Economics and Statistics, 72(1), 109-118. MABOGUNJE, A. L. (1995). The environmental challenges in sub-Saharan Africa. Environment: Science and Policy for Sustainable Development, 37(4), 4-10.

[48] MANAGI, S., HIBIKI, A. and TSURUMI, T. (2009). Does trade openness improve environmental quality?. Journal of environmental economics and management, 58(3), 346-363.

[49] MARTÍNEZ-ZARZOSO, I. and BENGOCHEA-MORANCHO, A. (2004). Pooled mean group estimation of an environmental Kuznets curve for $\mathrm{CO}_{2}$. Economics Letters, 82(1), 121-126.

[50] MAVROTAS, G., MURSHED, S. M. and TORRES, S. (2011). Natural resource dependence and economic performance in the 1970-2000 period. Review of Development Economics, 15(1), 124138.

[51] MO IBRAHIM (2014). Ibrahim index of African governance data report. Mo Ibrahim foundation. Retrieved December 15, 2014 from http://www.moibrahimfoundation.org /downloads/Publications/

[52] NISSANKE, M. K. (2001). Financing enterprise development in sub-Saharan Africa. Cambridge Journal of Economics, 25 (3), 343-368.

[53] OSABUOHIEN, E. S., EFOBI, U. R. and GITAU, C. M. (2013). External intrusion, internal tragedy: Environmental pollution and multinational corporations in sub-Saharan Africa. Advances in Sustainability and Environmental Justice, 12, 93-118. 
[54] OSABUOHIEN, E. S., EFOBI, U. R. and GITAU, C. M. W. (2014). Beyond the environmental Kuznets Curve in Africa: evidence from panel cointegration. Journal of Environmental Policy and Planning, 16(4). 571-538.

[55] OSBORNE, J. (2002). Notes on the use of data transformations. Practical Assessment, Research and Evaluation, 8(6), 1-8.

[56] OSTROM, E. (2008). Institutions and the Environment. Economic Affairs, 28(3), 23-31.

[57] OZTURK, I. and ACARAVCI, A. (2013). The long-run and causal analysis of energy, growth, openness and financial development on carbon emissions in Turkey. Energy Economics, 36, 262267.

[58] PANAYOTOU, T. (1997). Demystifying the environmental Kuznets curve: turning a black box into a policy tool. Environment and development economics, 2(4), 465-484.

[59] PESARAN, M. H. and SHIN, Y. (1998). An autoregressive distributed-lag modelling approach to cointegration analysis. Econometric Society Monographs, 31, 371-413.

[60] PESARAN, M. H. and SMITH, R. (1995). Estimating long-run relationships from dynamic heterogeneous panels. Journal of econometrics, 68(1), 79-113.

[61] PESARAN, M.H., SHIN, Y. and SMITH, R.P., (1999). Pooled Mean Group Estimation of Dynamic Heterogeneous Panels. Journal of the American Statistical Association, 94(446), 621634.

[62] RAJAN, R. G. and ZINGALES, L. (2003). The great reversals: the politics of financial development in the twentieth century. Journal of financial economics, 69(1), 5-50.

[63] PRS GROUP. (2015). International Country Risk Guide Methodology. The PRS Group.

[64] ROODMAN, D. (2009). How to do xtabond2: An introduction to difference and system GMM in Stata. Stata Journal, 9(1), 86.

[65] SACHS, J. D. and WARNER, A. M. (1997). Sources of slow growth in African economies. Journal of African economies, 6(3), 335-376.

[66] SADORSKY, P. (2010). The impact of financial development on energy consumption in emerging economies. Energy Policy, 38(5), 2528-2535.

[67] SAMARGANDI, N., FIDRMUC, J. and GHOSH, S. (2013). Is the relationship between financial development and economic growth monotonic for middle-income countries. Economics and Finance Working Paper, (13-21).

[68] SCHUMPETER, J.A., and OPIE, R. (1934). The theory of economic development; an inquiry into profits, capital, credit, interest, and the business cycle, Cambridge, Mass.: Harvard University Press.

[69] SELDEN, T. M. and SONG, D. (1994). Environmental quality and development: is there a Kuznets curve for air pollution emissions?. Journal of Environmental Economics and management, 27(2), 147-162.

[70] SHAFIK, N. and BANDYOPADHYAY, S. (1992). Economic growth and environmental quality: time series and cross-country evidence (No. 904). The World Bank.

[71] SHAHBAZ, M., HYE, Q. M. A., TIWARI, A. K. and LEITÃO, N. C. (2013). Economic growth, energy consumption, financial development, international trade and $\mathrm{CO}_{2}$ emissions in Indonesia. Renewable and Sustainable Energy Reviews, 25, 109-121.

[72] SHAHBAZ, M., KUMAR TIWARI, A. and NASIR, M. (2013). The effects of financial development, economic growth, coal consumption and trade openness on $\mathrm{CO}_{2}$ emissions in South Africa. Energy Policy, 61, 1452-1459.

[73] TAMAZIAN, A. and BHASKARA RAO, B. (2010). Do economic, financial and institutional developments matter for environmental degradation? Evidence from transitional economies. Energy Economics, 32(1), 137-145.

[74] TAMAZIAN, A., CHOUSA, J. P. and VADLAMANNATI, K. C. (2009). Does higher economic and financial development lead to environmental degradation: evidence from BRIC countries. Energy Policy, 37(1), 246-253. 
[75] TORRAS, M. and BOYCE, J. K. (1998). Income, inequality, and pollution: a reassessment of the environmental Kuznets curve. Ecological economics,25(2), 147-160.

[76] UNEKE, O. (2010). Corruption in Africa South of the Sahara: bureaucratic facilitator or handicap to development?. Journal of Pan African Studies, 3(6).

[77] VERBEKE, T. and DE CLERCQ, M. (2006). The income-environment relationship: evidence from a binary response model. Ecological Economics, 59(4), 419-428.

[78] WANG, Y. (forthcoming). Politically Connected Polluters Under Smog, in Business and Politics.

[79] WOLDE-RUFAEL, Y. (2009). Energy consumption and economic growth: the experience of African countries revisited. Energy Economics, 31(2), 217-224.

[80] YANG, Y. Y. and YI, M. H. (2008). Does financial development cause economic growth? Implication for policy in Korea. Journal of Policy Modeling, 30(5), 827-840.

[81] YOUNG, O. R. (2002). Institutional interplay: the environmental consequences of cross-scale interactions. The drama of the commons, 263-291.

[82] ZHANG, Y. J. (2011). The impact of financial development on carbon emissions: An empirical analysis in China. Energy Policy, 39(4), 2197-2203.

[83] ZIAEI, S. M. (2015). Effects of financial development indicators on energy consumption and CO2 emission of European, East Asian and Oceania countries. Renewable and Sustainable Energy Reviews, 42, 752-759.

*Corresponding author.

E-mail address: aliyumaiha@ gmail.com 